The northern Red

Sea - A system in balance?

C. Häse et al.

\title{
A system in balance? - Implications of deep vertical mixing for the nitrogen budget in the northern Red Sea, including the Gulf of Aqaba (Eilat)
}

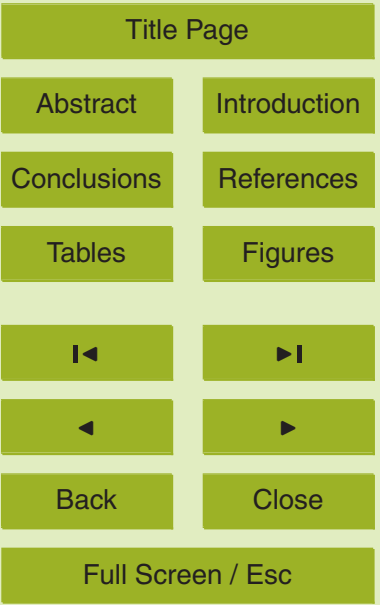

C. Häse ${ }^{1,{ }^{*}}$, M. Al-Qutob ${ }^{2,3}$, Z. Dubinsky ${ }^{2}$, E. A. Ibrahim ${ }^{4}$, B. Lazar ${ }^{5}$, N. Stambler ${ }^{2}$, and M. M. Tilzer ${ }^{6}$

${ }^{1}$ ZMT Bremen, 28359 Bremen, Germany

${ }^{2}$ Department of Life Sciences, Bar Ilan University, Ramat Gan, Israel

${ }^{3}$ Department of Biology, Faculty of Science and Technology, Al-Quds University, Palestinian

Full Screen / Esc Authority

${ }^{4}$ National Institute of Oceanography and Fisheries, Cairo, Egypt

${ }^{5}$ Institute of Earth Sciences and Moshe Shilo Centre for Biogeochemistry, The Hebrew

Printer-friendly Version University of Jerusalem, Jerusalem, Israel

${ }^{6}$ Aquatic Ecology, University of Constance, 78457 Konstanz, Germany 
* now at: GKSS Research Center, 21502 Geesthacht, Germany

Received: 6 February 2006 - Accepted: 13 February 2006 - Published: 26 April 2006

Correspondence to: C. Häse (clivia.haese@gkss.de)
BGD

3, 383-408, 2006

The northern Red

Sea - A system in balance?

C. Häse et al.

Title Page

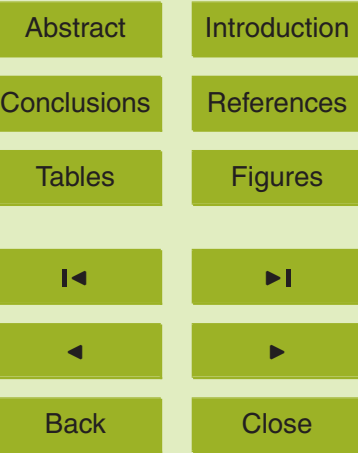

Full Screen / Esc

Printer-friendly Version

Interactive Discussion 


\section{Abstract}

We investigated the implications of deep winter mixing for the nitrogen budget in two adjacent systems, the northern Red Sea proper, and the Gulf of Aqaba. Both are subtropical oligotrophic water bodies. The main difference is that in the gulf deep winter 5 mixing takes place regularly, whereas the northern Red Sea proper is permanently stratified. In the Gulf of Aqaba, we observed significantly lower nitrate deficits, i.e. deviations from the Redfield ratio, than in the northern Red Sea proper. Assuming that other external inputs and losses in $\mathrm{N}$ or $\mathrm{P}$ are very similar in both systems, the higher nitrate deficit can be explained by either lower nitrogen fixation in the (stratified) northof benthic denitrification than in the gulf. By comparing the two systems we have indirect evidence that benthic denitrification was much lower in the Gulf of Aqaba due to higher oxygen concentrations. This we attributed to the occurrence of deep winter mixing, and as a consequence, the nitrate deficit was close to zero (i.e. N:P ratio close to "Redfield"). If both nitrogen fixation and benthic denitrification take place, as in the northern Red Sea proper, the result was a positive nitrate deficit (i.e. a deficit in nitrate) in the ambient water. The nitrate deficit in the northern Red Sea was observed in spite of high iron deposition from the surrounding desert. Our results strongly support the concept of nitrogen as the proximate, and phosphate as the ultimate limiting nutrient for primary production in the sea. This must not be neglected in efforts for protecting the adjacent reefs against eutrophication.

\section{Introduction}

Nitrogen $(\mathrm{N})$ and phosphorus $(\mathrm{P})$ are the nutrients potentially limiting phytoplankton production in the oceans. From considerations of the N:P ratios in phytoplankton cells, and in the ambient water, and from nutrient enrichment experiments, nitrogen was proposed to be the limiting nutrient (e.g. Codispoti, 1989; referred to as the "biologist's
BGD

3, 383-408, 2006

The northern Red

Sea - A system in balance?

C. Häse et al.

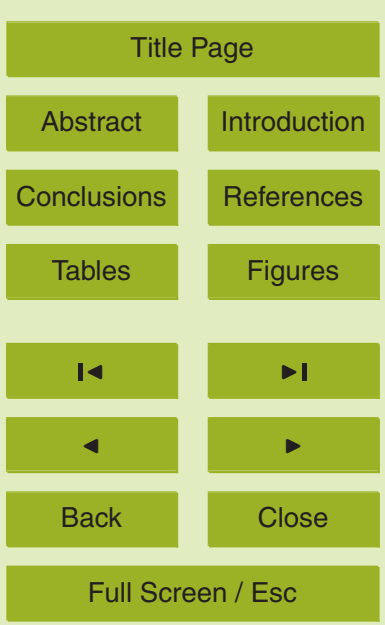

Printer-friendly Version

Interactive Discussion 
view"). Considering the evolution of biogeochemical cycles in the context of the evolution of the involved enzyme systems, Falkowski suggested that nitrogen is the limiting nutrient for primary production on geological time scales (Falkowski, 1997; Codispoti, 1997). On the other side, it is argued that nitrogen cannot be the limiting nutrient of 5 primary production as long as nitrogen fixation can take place. Since there is no equivalent influx process to the system for phosphorus, the $\mathrm{N}: \mathrm{P}$ ratio could principally be adjusted to phytoplankton demands by nitrogen fixation. Thus, on the long term phosphorus must be the nutrient controlling phytoplankton productivity (e.g. Tyrrell, 1999; Toggweiler, 1999; referred to as the "geochemist's view"). By model calculations, Tyrrell 10 (1999) pointed out that the proximate and the ultimate limiting nutrient (PLN and ULN) do not have to be the same nutrient species, even in a steady state system. The PLN "represents the local limiting nutrient according to Liebig's law", whereas the ULN "represents the nutrient whose supply rate forces total system productivity over long timescales" (Tyrrell, 1999). The model runs demonstrated that in marine systems ni15 trate is the PLN in surface waters, whereas phosphate is the ULN for the system.

The question whether nitrogen or phosphorus is regulating primary production in the ocean is connected to the question after the cause for the nitrate deficit that is observed in vast parts of the oceans (e.g. Gruber and Sarmiento, 1997). The mechanisms responsible for the nitrate deficit are not yet fully resolved. The imbalance between denitrification and nitrogen fixation is considered to play the key role in that. It is still under debate, whether the nitrate deficit is partly caused by iron limitation of nitrogen fixers (e.g. Falkowski, 1997; Toggweiler, 1999; Wu et al., 2000; Sañudo-Wilhelmy et al., 2001; Tyrrell et al., 2003). An alternative explanation was proposed by the competition between nitrogen-fixing and other phytoplankton (Tyrrell, 1999).

25 The present study investigates the oligotrophic northern part of the Red Sea, including the Gulf of Aqaba. The Gulf of Aqaba and the northern Red Sea proper (in the following referred to as the northern Red Sea) are adjacent water bodies that are connected by a shallow sill. Whereas the Red Sea can be considered as permanently stratified (Plähn et al., 2002), deep winter mixing occurs regularly in the gulf (Wolf-

\section{BGD}

3, 383-408, 2006

The northern Red

Sea - A system in balance?

C. Häse et al.

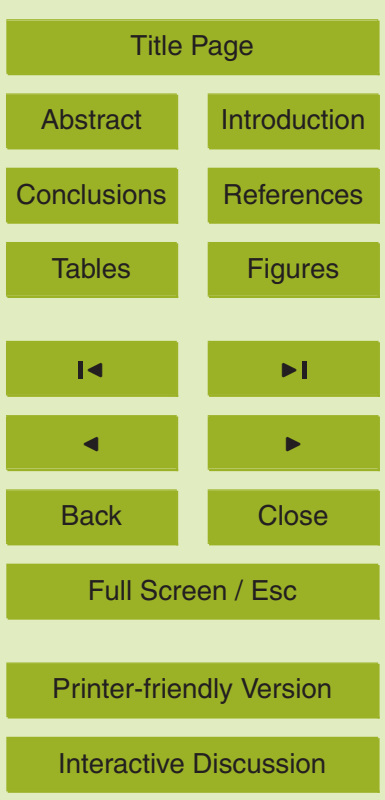

EGU 
Vecht et al., 1992; Genin et al., 1995; Manasrah et al., 2004). The aim of the present study is to investigate the implications of the deep mixing for the nitrogen budget, in particular for the nitrate deficit in the water column, by a comparative analysis of the two systems. Al-Qutob et al. (unpubl. manuscript) found N:P ratios close to the Redfield 5 ratio in the Gulf of Aqaba. By applying the concept of the nitrate deficit (e.g. Gruber and Sarmiento, 1997; Tyrrell and Lucas, 2002) we address the question, whether the nitrogen input and loss processes are in balance in the Gulf of Aqaba. We report on field observations from a unique marine system that provide evidence for reconciling "the biologist's and the geochemist's views".

\section{Study site}

The Red Sea has a tectonic origin as a transform fault of the East African Rift Valley system. It is located in an arid climate zone with negligible precipitation and terrestrial run-off. High evaporation rates in the region $\left(1 \mathrm{~cm} \mathrm{~d}^{-1}\right.$ in the gulf, cf. Wolf-Vecht et al., 1992; and $2.1 \mathrm{~m} \mathrm{a}^{-1}$ in the Red Sea, Sofianos et al., 2002) cause a negative hydro15 logical budget which is compensated by a net water inflow into the Red Sea through the shallow sill $(140 \mathrm{~m})$ at Bab-al-Mandeb (Longhurst, 1998). The thermohaline circulation pattern at Bab-al-Mandeb of surface inflow and subsurface outflow (Longhurst, $1998)$ is repeated at the second shallow sill $(250 \mathrm{~m})$ at the Straits of Tiran (Reiss and Hottinger, 1984). During the study period, inflow into the gulf occurred in the 35-70 m

20 layer, and outflow below $70 \mathrm{~m}$ (Manasrah et al., 2004). Water renewal times in the top $200 \mathrm{~m}$ layer in the Red Sea were estimated to six years, and for the entire water body to around 200 years (UNEP, 1997), whereas a recent study report on 30-45 years for the deep water in the Red Sea (Plähn et al., 2002). The water renewal time in the Gulf of Aqaba was determined to between 1 and 2 years (cf. Hulings, 1989). The waters are highly transparent with euphotic depths (1-\% light level) in the range of $77-105 \mathrm{~m}$ in the Gulf of Aqaba, and 74-94 $\mathrm{m}$ in the northern Red Sea during the study period (Stambler, 2005). The entire area is surrounded by desert from which large amounts

\section{BGD}

3, 383-408, 2006

The northern Red

Sea - A system in balance?

C. Häse et al.

Title Page

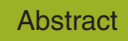

Introduction

Conclusions

Tables

References

Figures

14

-1

4

Back

Close

Full Screen / Esc

Printer-friendly Version

Interactive Discussion 
of dust are deposited on the water surface. Even though both water bodies are closely interconnected, they differ in their hydrodynamic regimes. The Red Sea is permanently stratified with high nutrient concentrations in deep waters being effectively separated from the nutrient-depleted euphotic zone by a strong pycnocline (e.g. Longhurst, 1998).

5 By contrast, in the Gulf of Aqaba deep winter mixing occurs regularly (Wolf-Vecht et al., 1992; Genin et al., 1995; Manasrah et al., 2004), in some years even down to the sea floor at the northern end of the gulf (i.e. $>700 \mathrm{~m}$ ). The southern Red Sea is considered a highly productive system (Reiss and Hottinger, 1984; Longhurst, 1998). As the surface waters flow north, the dissolved nutrients are removed by phytoplankton uptake, 10 so that $2000 \mathrm{~km}$ to the north nutrient-depleted surface waters enter the Gulf of Aqaba through the Straits of Tiran (Reiss and Hottinger, 1984). In the gulf, the vertical distribution of nutrients is the result of alternating stratification during summer, then resembling the situation in the Red Sea, and deep vertical mixing in winter, resulting in a homogeneous distribution of nutrients within the mixed layer (e.g. Al-Qutob et al., unpubl. manuscript). Like in most (sub)tropical oligotrophic seas, nitrate was mostly considered to be the controlling nutrient for primary production in the Red Sea, including the Gulf of Aqaba (Levanon-Spanier et al., 1979; Reiss and Hottinger, 1984; Weikert, 1987; Badran et al., 2005). By contrast, Naqvi et al. (1986) reported on nitrogen export from the Red Sea into the Gulf of Aden, and Hulings considered phosphate as the

limiting nutrient for primary production in the Gulf of Aqaba (cf. Hulings, 1989). However, a recent study reports on co-limitation of both nutrients (Al-Qutob et al., unpubl. manuscript). In both water bodies extensive blooms of Trichodesmium do occur (Kimor and Golandski, 1977; Weikert, 1987; Böttger-Schnack and Schnack, 1989; Longhurst, 1998; Post et al., 2002).

\section{BGD}

3, 383-408, 2006

The northern Red

Sea - A system in balance?

C. Häse et al.

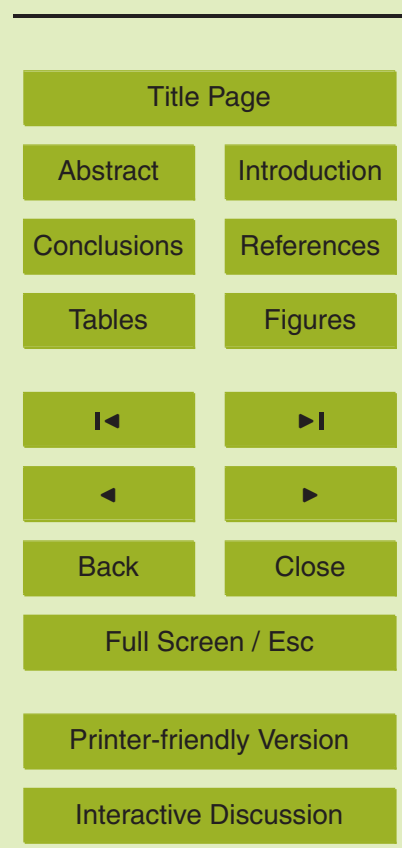

EGU 


\section{Methods}

\subsection{Field measurements}

BGD

The nutrient regime in the Gulf of Aqaba was monitored for three years from January 1997 to December 1999 by monthly one-day cruises to the routine station of the Red

5 Sea Program at the northern tip of the gulf (Station I, Fig. 1). Additional data were collected in the Gulf of Aqaba, and in the northern Red Sea during the 44/2 cruise of RV "Meteor" from February 21 until 8 March 1999.

For some unknown reason, the N:P ratios observed in the gulf during the two-weeks RV "Meteor" 44/2 cruise in February/March 1999 were in general lower than the values derived from the one-day cruises to Station I. This applied even to the one-day cruises in Spring 1999 just before and after the "Meteor" cruise. The data were thoroughly checked and found to be consistent. It seemed to be a systematic trend in the entire data set from the "Meteor" cruise. Therefore, and because no data from other cruises were available for the northern Red Sea, we considered in the present study only the data collected during the "Meteor" cruise for the comparison of the two systems.

Sample collection was performed by a trace metal-clean rosette with 10-L Niskin bottles using clean Tygon tubing. Sample tubes were thoroughly flushed with sample water before filling. Measurements of nutrient concentrations were carried out within $24 \mathrm{~h}$ after sampling, meanwhile samples were stored cool and dark. Nutrient concentra20 tions were measured by a Flow Injection Analyzer (FIA Quick - Chem 8000). Oxygen concentrations were determined by Winkler titration. Mixing depths were determined from CTD-data and nutrient (mainly nitrate) gradients. Trace metal concentrations were determined by atomic absorption spectrometry (data not shown).

3.2 Calculation of the nitrate deficit and the apparent oxygen utilization (AOU)

25 The apparent oxygen utilization (AOU) in the water column was calculated for each vertical profile by integrating the saturated oxygen concentration according to the actual

The northern Red

Sea - A system in balance?

C. Häse et al.

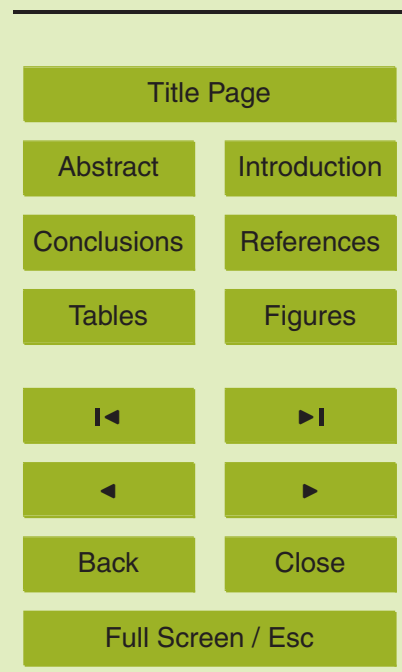

Printer-friendly Version

Interactive Discussion 
vertical distribution of temperature and salinity. Then the depth-integral of the actual measurements was subtracted.

The water-column nitrate deficit was calculated by subtracting the depth-integral of total oxidized nitrogen concentrations from the 16-fold of the vertical integral of phos5 phate concentrations.

\section{Results}

\subsection{Mixing depths}

The "Meteor" cruise took place during the height of the mixing season in 1999. At the beginning of the cruise, mixing depths in the Gulf of Aqaba were about 200-300 m with 10 a slight peak in the middle stations (II-IV), and lower values at both ends of the gulf (stations I, V, and VI). During the two-weeks period of the cruise, the mixing depth in the gulf increased, reaching maximum values at the northern end of the gulf (station I). By the end of the cruise, a north-south gradient had established with values between $250 \mathrm{~m}$ in the south, and 400-500 m in the north. By contrast, in the northern Red Sea

no such pattern nor any trends were observed. While surface cooling and wind stirring allowed mixing down to $500 \mathrm{~m}$ in the Gulf of Aqaba, mixing depths in the northern Red Sea were generally in the range of $20-75 \mathrm{~m}$, interrupted by single, local mixing events reaching about $100 \mathrm{~m}$ depth. The mixing hardly exceeded the euphotic zone (74-94 m; Stambler, 2005). Thus, in the northern Red Sea there was virtually no exchange in oxygen or nutrients between the upper mixed layer and the deep waters, not even during the mixing season.

\section{BGD}

3, 383-408, 2006

The northern Red

Sea - A system in balance?

C. Häse et al.

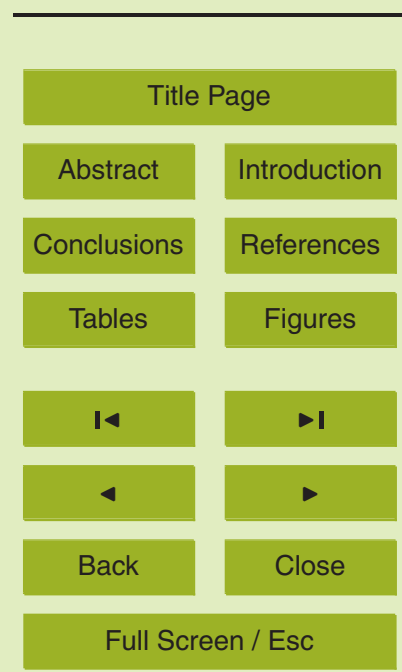

Printer-friendly Version

Interactive Discussion The average $N: P$ ratio for each system was determined by a linear regression analy- 
addition, the average nitrate deficit was calculated for each pair of total oxidized nitrogen and phosphate measurements. We followed the definition by Tyrrel and Lucas (2002): $\Delta \mathrm{N}=16 \times\left[\mathrm{PO}_{4}^{3-}\right]-\left[\mathrm{NO}_{3}^{-}\right]$, except that we used total oxidized nitrogen instead of nitrate, because the presence of nitrite in the water column was attributed to nitrite ex5 cretion by phytoplankton (Al-Qutob et al., 2002), presumably originating from previous phytoplankton uptake of nitrate.

The differences between the two systems were highly significant: The differences in N:P ratios were tested by a General Linear Model $(p<0.005)$, nitrate deficits were compared by a two-sided t-Test $\left(p=9.9 \times 10^{-10}\right)$. In the Gulf of Aqaba, the nitrate deficit 10 was lower with less variance than in the northern Red Sea (Fig. 2, Table 1). This was also reflected in a lower N:P ratio in the northern Red Sea compared to the gulf (Table 1).

The nitrate deficit in the water column was related to the maximum water depth that was considered in the calculations (Fig. 3). Note, that this depth did not correspond at all stations to the water depth (see Table 2). In the northern Red Sea, the water-column nitrate deficit did in addition depend on the location within the basin (compare Fig. 1).

\subsection{Nitrate deficit and oxygen}

Figure $4 a$ shows an example of typical vertical oxygen profiles in each system. In the Gulf of Aqaba, oxygen concentrations were high even far below the actual mixing 20 depth (200 m, Stn. V, 21 February 1999), where the water neither had contact with the atmosphere nor was enriched with oxygen by phytoplankton production for at least a year. Values below $170 \mathrm{mmol} / \mathrm{m}^{3}$ we never observed in the gulf (mainly Station I) during the entire study period from 1997 until 1999. By contrast, in the northern Red Sea oxygen concentrations rapidly decreased below the euphotic zone, which exceeded 25 usually the actual mixing depth (50 m, Stn. X, 24/2/1999). A local oxygen minimum of about $80 \mathrm{mmol} / \mathrm{m}^{3}$ was pronounced at all stations, usually in the $400-600 \mathrm{~m}$ depth layer.

The nitrate deficit in both water bodies increased with depth, and inversely reflected

\section{BGD}

3, 383-408, 2006

The northern Red

Sea - A system in balance?

C. Häse et al.

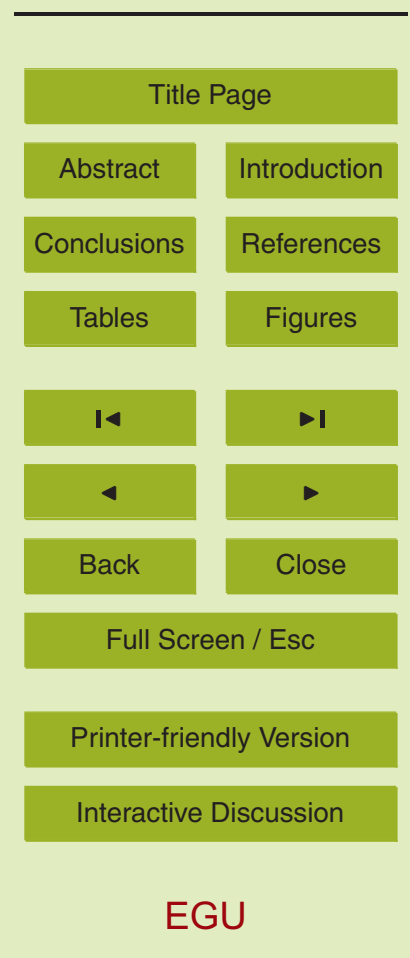


the oxygen concentrations (Fig. 4b). In the Gulf of Aqaba, the nitrate deficit of the upper mixed layer was always close to zero, and sometimes even negative (i.e. excess nitrogen) at saturating oxygen concentrations.

The apparent oxygen utilization (AOU) in the water column was linearly related to 5 the water-column nitrate deficit (Fig. 5). The water-column AOU explained $98 \%$ of the variance in the water-column nitrate deficit in the Gulf of Aqaba (slope $=0.03$, intercept $=0.15 \mathrm{~mol} \mathrm{~m}^{-2}$ ), and $82 \%$ for the entire data set.

\subsection{Preformed nutrients}

The relationship of water-column AOU with the amount of phosphate in the water column was highly significant, and followed the same straight line in both water bodies. The slope was very close to the theoretical value of 138 mole $\mathrm{O}_{2}$ per mole of phosphate according to Redfield et al. (1963). Likewise, was the slope for total oxidized nitrogen quite close to the theoretical value of 8.6 mole $\mathrm{O}_{2}$ per mole of nitrate in the Gulf of Aqaba. Deviations from that line were observed only in the northern Red Sea, especially at the deeper stations of the basin (Fig. 6). Furthermore, our data indicate that the concentrations of preformed nutrients were small for $\mathrm{N}$ and $\mathrm{P}$ in both water bodies (not shown).

\section{Discussion}

In the Gulf of Aqaba, we observed nitrate deficits very close to zero at saturating oxygen concentrations within the mixed layer (see example in Fig. 4). The generally higher nitrate deficit in the northern Red Sea compared to the gulf is either the consequence of lower nitrogen fixation or of higher nitrogen losses in the northern Red Sea. Due to the high oxygen levels in both water bodies, even denitrification in anoxic microzones of aggregates seems to be unlikely (personal communication L. A. Codispoti,

\section{BGD}

3, 383-408, 2006

The northern Red

Sea - A system in balance?

C. Häse et al.

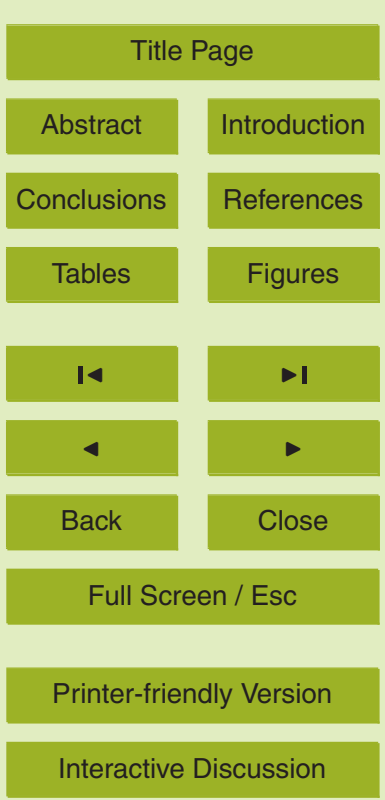

EGU 
row basin, benthic denitrification seems to be the main loss process for nitrogen in the Red Sea (personal communication D. M. Sigman). An alternative explanation would be some unrecognized pathway that removes oxidized nitrogen from the ambient water at the presence of high oxygen levels. To further clarify this uncertainty, direct measure5 ments of denitrification rates and other possible loss processes should be undertaken in the area. In addition, vertical fluxes of organic carbon should be considered to make up a budget for benthic denitrification.

\subsection{Nitrogen fixation}

Trichodesmium blooms are well known to occur in the upper $100 \mathrm{~m}$ of the water col10 umn in the Gulf of Aqaba, and in the Red Sea (Kimor and Golandski, 1977; Weikert, 1987; Böttger-Schnack and Schnack, 1989; Longhurst, 1998; Post et al., 2002). Trichodesmium blooms follow extreme nitrogen depletion, the times of massive occurrence in the area are June, and October/November (Kimor and Golandsky, 1977; Post et al., 2002). The cellular N:P ratio of Trichodesmium is often well above the Redfield 5 ratio (Sanudo-Wilhelmy et al., 2001). By subsequent remineralization of a massive Trichodesmium bloom, the ambient water becomes enriched with nitrogen relative to phosphorus. The fixed nitrogen is transported into deeper water layers via sedimentation or vertical mixing, and in addition via grazing by the vertically migrating copepod Macrosetella gracilis, the main feeder on Trichodesmium in the area (Böttger-Schnack 20 and Schnack, 1989). The nitrogen enrichment by Trichodesmium was proposed to significantly contribute to the seasonal changes in N:P ratios observed in the gulf (AlQutob et al., unpubl. manuscript).

Trichodesmium blooms develop only in stratified waters, as soon as the mixing depth exceeds about $100 \mathrm{~m}$, the bloom ceases (Weikert, 1987; Capone et al., 1997; Post et 25 al., 2002; Tyrrell et al., 2003). Therefore, it seems unlikely that nitrogen fixation by Trichodesmium is lower in the stratified northern Red Sea than in the Gulf of Aqaba where deep winter mixing occurs regularly. Furthermore, a possible difference in nitrogen fixation between the two water bodies could hardly be explained by iron limitation

\section{BGD}

3, 383-408, 2006

The northern Red

Sea - A system in balance?

C. Häse et al.

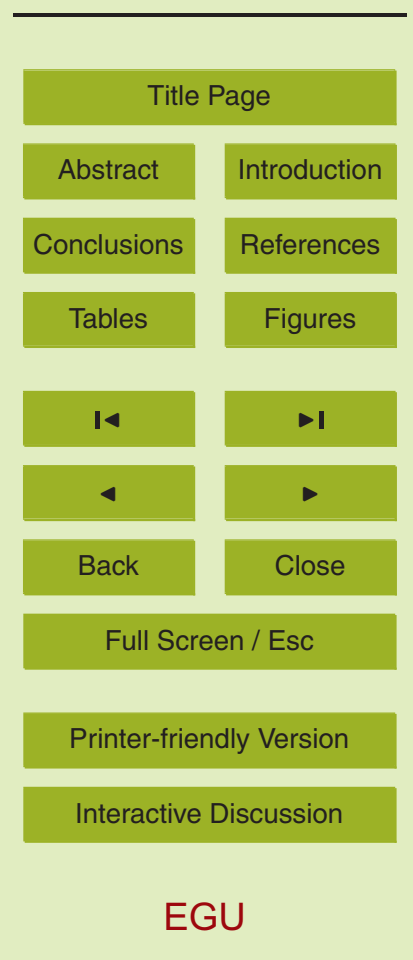


of nitrogen fixation due to high deposition of dust from the surrounding deserts in the entire area.

In tropical and subtropical oligotrophic oceans Trichodesmium is considered the main nitrogen fixing organism (Capone et al., 1997, 2005). In addition, there is recent ev5 idence for a significant contribution to nitrogen fixation by unicellular cyanobacteria (Zehr et al., 2001; Montoya et al., 2004). The contribution of unicellular cyanobacteria to nitrogen fixation in the Red Sea is to the best of our knowledge unclear, so far. A recent study on the distribution of unicellular diazotrophs along a transect from the Seychelles to Oman revealed a considerably reduced abundance of these organisms

10 at water temperatures below $29^{\circ} \mathrm{C}$ (Mazard et al., 2004). Even in the southern Red Sea, temperatures in this range are restricted to limited time periods (Sofianos et al., 2002), which may severely constrain a significant contribution of these organisms to nitrogen fixation in the northern Red Sea.

\subsection{Nitrogen losses}

15 The fact that the nitrate deficit in both water bodies inversely reflected the oxygen concentration throughout the water column (Fig. 4) strongly suggests that the formation of the nitrate deficit is regulated by the level of oxygen.

Considering benthic denitrification as the main loss process for nitrogen in the Red Sea, the observed pattern in the water chemistry can be explained only by a strong 20 benthic-pelagic coupling in the system. Remineralization rates are supposed to be fast in the high-temperature environment of both water bodies. The location of the oxygen minimum indicates the depth layer where the losses of oxidized nitrogen are most pronounced (Fig. 4). This implies that the oxygen level in the water column affects to some extent the denitrification rates in the corresponding sediment layers around 25 the basin. On the other hand, the linear relationship between the AOU and the nitrate deficit in the water column (Fig. 5) implies that benthic denitrification removes nitrate from the water column, even at locations far from the shore (Fig. 1). This requires a strong physical interaction between water and sediment, and can be explained only by

\section{BGD}

3, 383-408, 2006

The northern Red

Sea - A system in balance?

C. Häse et al.

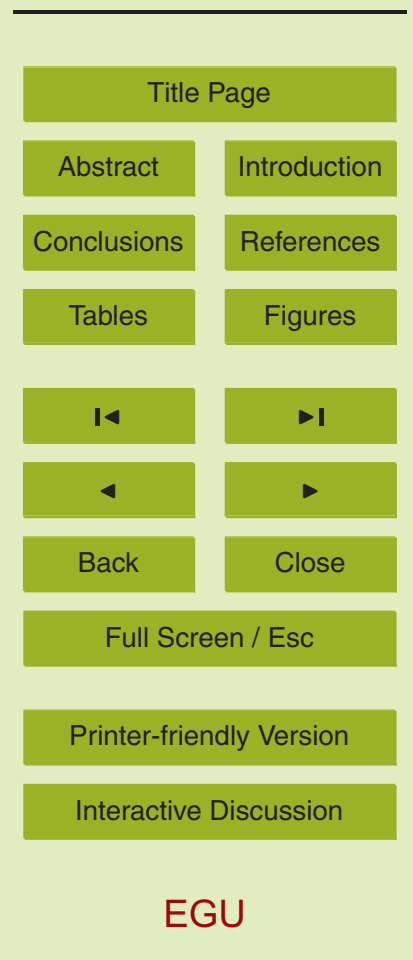


intensive horizontal water circulation in the narrow and steep basins of the Red Sea, and the Gulf of Aqaba (Wolf-Vecht et al., 1992; Manasrah et al., 2004). The overall difference in the nitrate deficit between the two water bodies would then be attributable to the different water residence times in the two basins.

5 The data presented in Figs. 5 and 6 suggest that the nutrient regime especially in the gulf is in accordance with the "Redfield" stoichiometry, and is mainly ruled by internal biogeochemical cycles. Both relationships revealed a higher variance in the northern Red Sea than in the gulf (Figs. 5 and 6). Deviations occurred in particular at the deep stations in the northern Red Sea and at the most western station (Fig. 1), which seems to be related to the longer residence time of deep and bottom water compared to that in the upper layers, and to the exchange of water masses between the northern Red Sea and the two adjacent gulfs (Aqaba and Suez) at the different stations (Plähn et al., 2002).

From the difference in the two systems we conclude that the process responsible for

the nitrogen losses in the system is suppressed by high oxygen concentrations in the gulf. In this context, the deep winter mixing plays a key role by resetting the oxygen concentrations back to the saturation value within the mixed layer.

\subsection{The role of iron for the nitrogen budget}

As nitrogen fixation seems to be released from iron limitation in the region of the Red 20 Sea, one should expect that the nitrate deficit would disappear, and N:P ratios would increase to values close to the Redfield ratio. This was observed only in the Gulf of Aqaba, but not in the northern Red Sea. Consequently, a different mechanism must be responsible for the nitrate deficit observed in the northern Red Sea.

Tyrrell (1999) pointed out that an overall ocean nitrate deficit is compatible with a 25 system in steady state which can be attributed to the competition between nitrogen fixers and other phytoplankton. Nitrogen fixers pay higher energetic costs for fixing nitrogen than non-fixing phytoplankton, which results in lower maximum growth rates (Capone et al., 1997; Tyrrell, 1999).
BGD

3, 383-408, 2006

The northern Red

Sea - A system in balance?

C. Häse et al.

Title Page

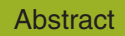

Introduction

Conclusions

Tables

References

Figures

14

4

Back

Close

Full Screen / Esc

Printer-friendly Version

Interactive Discussion 
Moreover, recent studies report that nitrogen fixation rates in the central Atlantic Ocean seem to be rather stimulated by phosphate-containing dust than by levels of dissolved iron in the ambient water (Sañudo-Wilhelmy et al., 2001; Tyrrell et al., 2003).

\subsection{Concept of PLN and ULN}

5 In conclusion of all the different mechanisms and processes considered above, we propose that benthic denitrification as the loss process in combination with the competition between nitrogen fixers and other phytoplankton causes the nitrate deficit in the waters of the oligotrophic Red Sea. If the loss process is suppressed, as we observed in the Gulf of Aqaba, the result is an N:P ratio very close to "Redfield". This clearly

10 supports the concept that phosphate is the ultimate limiting nutrient for primary production, which should not be neglected in the efforts that are undertaken for protecting the marine systems against eutrophication. In the Gulf of Aqaba, the industrial mining and subsequent shipping of phosphate leads to episodic phosphorus enrichment of surface waters (Klinker et al., 1978), which on the long term might be a threat for the adjacent coral reefs in the area. The negative consequences of high nutrient inputs for the coral reefs in the Gulf of Aqaba was drastically demonstrated by an intense winter mixing after the eruption of mount Pinatubo (Genin et al., 1995).

\section{Conclusions}

The differences in the hydrodynamic regime between the Gulf of Aqaba and the northern Red Sea were found to have far reaching consequences for the nitrogen budget in the two water bodies. From our study we conclude the following:

1. The process responsible for nitrogen losses was suppressed by high oxygen concentrations in the gulf due to deep winter mixing.

\section{BGD}

3, 383-408, 2006

The northern Red

Sea - A system in balance?

C. Häse et al.

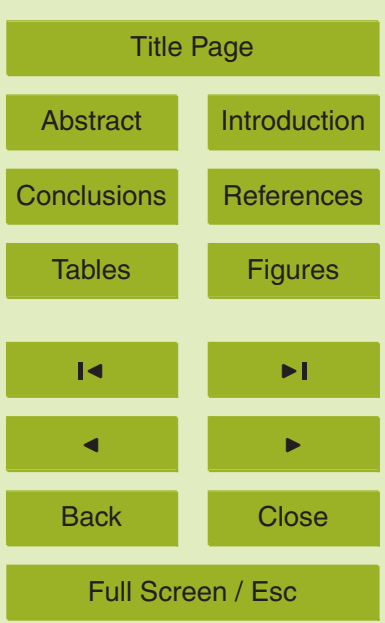

Printer-friendly Version

Interactive Discussion 
2. If both nitrogen fixation and the loss process took place, as observed in the northern Red Sea, the result was a positive nitrate deficit in the ambient water which could not be attributed to iron limitation of nitrogen fixation.

\section{BGD}

3, 383-408, 2006

3. Our field data strongly support the concept of phosphate as the ultimate limiting nutrient for primary production in the sea (Tyrrell, 1999). This concept should be considered for protecting the coral reefs in the Red Sea, and marine environments in general against eutrophication.

Acknowledgements. This research was funded by the Red Sea Program for Marine Sciences, grants no. 03F0151A and no. 03F0245A of the German Federal Ministry of Education and

10 Research (BMBF, Germany). C. Häse was partly supported by the Alfred Wegener Intstitute, Bremerhaven (Germany). We wish to express our thanks to the coordinator G. Hempel, the program's secretaries C. Richter and P. Westhaus-Ekau, and to the members of the steering committee of the Red Sea Program, E. Neher, G. Hempel, H. K. Badawi, M. Spira, and I. Khater for general support, and all colleagues participating in the Red Sea Program for throw15 ing bridges across the fences. We thank O. Plähn for providing CTD data of the RV "Meteor" cruise 44/2, A. Post and B. Kimor for providing information on Trichodesmium dynamics in the Red Sea, and M. Dray for excellent technical support, for help in logistics, and for performing the never-ending oxygen titrations during the cruise. Assistance by the technical staff of the IUI in Eilat is appreciated. Further, we wish to thank the captains and the crews of the research vessels "Suellyn", "Sea Surveyor", and "Meteor". W. Naqvi, L. Codispoti, H. Pearl, D. Sigman, and R. Elmgren we thank for inspiring discussions during the "SPOT-ON" workshop in Warnemünde, and for pointing out that neglecting nitrogen in measures for conservation of aquatic systems is of great danger. We wish to emphasize here that the message of this article should not be misunderstood in the sense that one has to care only about phosphorus.

\section{References}

Al-Qutob, M., Häse, C., Tilzer, M., and Lazar, B.: Phytoplankton Drives Nitrite Dynamics in the Gulf of Aqaba, Red Sea, Mar. Ecol. Prog. Ser., 239, 233-239, 2002.

The northern Red

Sea - A system in balance?

C. Häse et al.

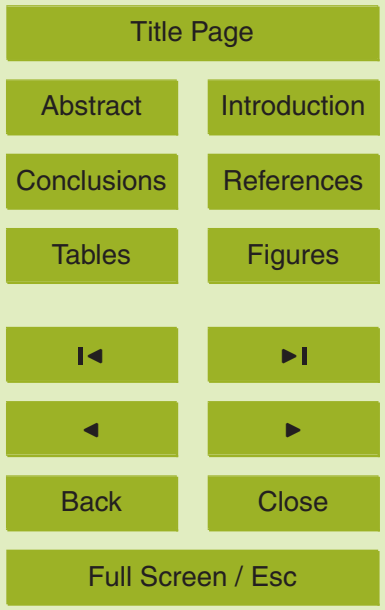

Printer-friendly Version

Interactive Discussion 
Capone, D. G., Zehr, J. P., Pearl, H. W., Bergman, B., and Carpenter, E. J.: Trichodesmium, a globally significant marine cyanobacterium, Science, 276, 1221-1229, 1997.

Capone, D. G., Burns, J. A., Montoya, J. P., Subramaniam, A., Mahaffey, C., Gunderson, T., Michaels, A. F., and Carpenter, E. J.: Nitrogen fixation by Trichodesmium spp: An impor5 tant source of new nitrogen to the tropical and subtropical North Atlantic Ocean, Global Biogeochem. Cycles, 19, GB2024, doi:10.1029/2004GB002331, 2005.

Codispoti, L. A.: The limits to growth, Nature, 187, 237-238, 1997.

Codispoti, L. A.: Phosphorus vs. nitrogen limitation of new export production, p. 377-394, in: Productivity of the ocean: Present and past, edited by: Berger, W. H., Toggweiler, J. R.,

10 Falkowski, P., Sarmiento, J. L., and Karl, D., Wiley, 1989.

Falkowski, P. G.: Evolution of the nitrogen cycle and its influence on the biological sequestration of $\mathrm{CO}_{2}$ in the ocean, Nature, 387, 273-275, 1997.

Genin, A., Lazar, B., and Brenner, S.: Vertical mixing and coral death in the Red Sea following the eruption of mount Pinatubo, Nature, 377, 507-510, 1995.

Hulings, N. C.: A review of marine science research in the Gulf of Aqaba, Publications of the Marine Science Station Aqaba, Jordan, No. 6, The University of Jordan Press, Amman, 1989.

Kimor, B. and Golandsky, B.: Microplankton of the Gulf of Elat: Aspects of seasonal and bathymetric distribution, Mar. Biol., 42, 55-67, 1977.

20 Klinker, J., Reiss, Z., Kropach, C., Levanon, I., Harpaz, H., and Shapiro, Y.: Nutrients and biomass distribution in the Gulf of Aqaba Elat, Red Sea, Mar. Biol., 45, 53-64, 1978.

Levanon-Spanier, I., Padan, E., and Reiss, Z.: Primary production in a desert-enclosed sea the Gulf of Elat Aqaba, Red Sea, Deep-Sea Res., 26, 673-685, 1979.

Longhurst, A.: Ecological Geography of the Sea, Academic Press, 1998.

Manasrah, R., Badran, M., Lass, H. U., and Fennel, W.: Circulation and winter deep-water formation in the northern Red Sea, Oceanologia, 46, 5-23, 2004.

Mazard, S. L., Fuller, N. J., Orcutt, K. M., Bridle, O., and Scanlan, D. J.: PCR analysis of the distribution of unicellular cyanobacterial diazotrophs in the Arabian Sea, Appl. Environ. Microbiol., 70, 7355-7364, 2004.

so Montoya, J. P., Holl, C. M., Zehr, J. P., Hansen, A., Villareal, T. A., and Capone, D. G.: High rates of $\mathrm{N}_{2}$ fixation by unicellular diazotrophs in the oligotrophic Pacific Ocean, Nature, 430, 1027-1031, 2004.

Naqvi, S. W. A., Hansen, H. P., and Kureishy, T. W.: Nutrient uptake and regeneration ratios in

\section{BGD}

3, 383-408, 2006

The northern Red

Sea - A system in balance?

C. Häse et al.

Title Page

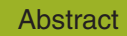

Introduction

Conclusions

Tables

References

Figures

14

4

Back

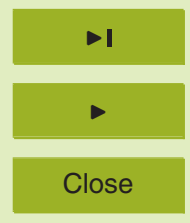

Full Screen / Esc

Printer-friendly Version

Interactive Discussion 
the Red Sea with reference to the nutrient budgets, Oceanol. Acta, 9, 271-275, 1986.

Plähn, O., Baschek, B., Badewien, T. H., Walter, M., and Rhein, M.: Importance of the Gulf of Aqaba for the formation of bottom water in the Red Sea, J. Geophys. Res.-Oceans, 107(22), $1-18,2002$.

5 Post, A. F., Dedej, Z., Gottlieb, R., Li, H., Thomas, D. N., El-Absawi, M., El-Naggar, A., ElGharabawi, M., and Sommer, U.: Spatial and temporal distribution of Trichodesmium spp. in the stratified Gulf of Aqaba, northern Red Sea, Mar. Ecol. Prog. Ser, 239, 241-250, 2002.

Redfield, A. C., Ketchum, B. H., and Richards, F. A.: The influence of organisms on the composition of sea-water, pp. 26-77, in: The Sea, vol. 2, edited by: Hill, M. N., Wiley-Interscience,

$10 \quad$ New York, 1963.

Reiss, Z. and Hottinger, L.: The Gulf of Aqaba. Ecological micropalaeontology, Springer, Berlin, 1984.

Sañudo-Wilhelmy, S. A., Kustka, A. B., Gobler, C. J., Hutchins, D. A., Yang, M., Lwiza, K., Burns, J., Capone, D. G., Raven, J. A., and Carpenter, E. J.: Phosphorus limitation of nitrogen

Sofianos, S. S., Johns, W. E., and Murray, S. P.: Heat and freshwater budgets in the Red Sea from direct observations at Bab el Mandeb, Deep-Sea Res. II, 49, 1323-1340, 2002.

Stambler, N.: Bio-optical properties of the northern Red Sea and the Gulf of Eilat (Aqaba) during winter 1999, J. Sea Res., 54, 186-203, 2005.

20 Toggweiler, J. R.: An ultimate limiting nutrient, Nature, 400, 511-512, 1999.

Tyrrell, T.: The relative influences of nitrogen and phosphorus on oceanic primary production, Nature, 400, 525-530, 1999.

Tyrrell, T. and Lucas, M. I.: Geochemical evidence of denitrification in the Benguela upwelling system, Cont. Shelf Res., 22, 2497-2511, 2002.

Tyrrell, T., Marañón, E., Poulton, A. J., Bowie, A. R., Harbour, D. S., and Woodward, E. M. S.: Large-scale latitudinal distribution of Trichodesmium spp. in the Atlantic Ocean, J. Plankt. Res., 25, 405-416, 2003.

UNEP: Assessment of land-based sources and activities affecting the marine environment in the Red Sea and Gulf of Aden, UNEP Regional Seas Reports and Studies, No. 166, United Nations Environment Programme, 1997.

Weikert, H.: Plankton and the pelagic environment, p. 90-111, in: Red Sea, Key Environments, edited by: Edwards, A. J. and Head, S. M., Pergamon Press, Oxford, 1987.

Wolf-Vecht, A., Paldor, N., and Brenner, S.: Hydrographic indications of advection/convection
BGD

3, 383-408, 2006

The northern Red

Sea - A system in balance?

C. Häse et al.

Title Page

Abstract

Introduction

Conclusions

Tables

References

Figures

14

$\rightarrow 1$

4

Back

Close

Full Screen / Esc

Printer-friendly Version

Interactive Discussion 
effects in the Gulf of Elat, Deep-Sea Res., 39, 1393-1401, 1992.

Wu, J., Sunda, W., Boyle, E. A., and Karl, D. M.: Phosphate depletion in the Western North Atlantic Ocean, Science, 289, 759-762, 2000.

Zehr, J. P., Waterbury, J. B., Turner, P. J., Montoya, J. P., Omoregie, E., Steward, G. F., Hansen, $5 \quad$ A., and Karl, D. M.: Unicellular cyanobacteria fix $\mathrm{N}_{2}$ in the subtropical North Pacific Ocean, Nature, 412, 635-638, 2001.

\section{BGD}

3, 383-408, 2006

\section{The northern Red}

Sea - A system in balance?

C. Häse et al.

\section{Title Page}

Abstract Introduction

Conclusions References

Tables Figures

14

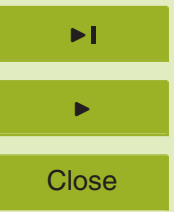

Back 
BGD

3, 383-408, 2006

\section{The northern Red}

Sea - A system in balance?

C. Häse et al.

Table 1. Comparison of the "Redfield" characteristics in the Gulf of Aqaba and the northern Red Sea. N:P ratios and nitrate deficits were calculated from pairs of total oxidized nitrogen and phosphate concentrations collected from all stations in both systems. Differences in N:P ratios between the two systems were tested by a General Linear Model $(p<0.005)$, nitrate deficits were compared by a two-sided t-Test $\left(p=9.9 \times 10^{-10}\right)$.

\begin{tabular}{llllllll}
\hline & & & N:P ratio & & \multicolumn{2}{c}{$\begin{array}{c}\text { Nitrate deficit } \\
\left(\mathrm{mmol} / \mathrm{m}^{3}\right)\end{array}$} \\
\hline Statistical measure & $n$ & slope & intercept & $r^{2}$ & Mean & SD \\
\hline Gulf of Aqaba & 151 & $13.1 \pm 0.3$ & $0.1 \pm 0.1$ & 0.94 & 0.3 & 0.6 \\
Northern Red Sea & 79 & $11.3 \pm 0.4$ & $0.2 \pm 0.3$ & 0.90 & 2.2 & 2.4 \\
\hline
\end{tabular}


Table 2. Water column chemistry at the different stations sampled in the Gulf of Aqaba and the northern Red Sea. Note that the maximum sampling depth did not correspond at all stations to the water depth.

\begin{tabular}{|c|c|c|c|c|c|c|c|c|}
\hline \multicolumn{2}{|c|}{ Station } & Latitude & Longitude & Date & $\begin{array}{c}\text { Water } \\
\text { depth }(m)\end{array}$ & $\begin{array}{l}\text { Max. spl. } \\
\text { depth (m) }\end{array}$ & $\begin{array}{l}\mathrm{N} \text { deficit } \\
\left(\mathrm{mol} / \mathrm{m}^{2}\right)\end{array}$ & $\begin{array}{c}\mathrm{AOU} \\
\left(\mathrm{mol} / \mathrm{m}^{2}\right)\end{array}$ \\
\hline \multicolumn{9}{|c|}{ Gulf of Aqaba } \\
\hline 1 & $122 / 9$ & $29.492 \mathrm{~N}$ & $34.950 \mathrm{E}$ & 22/02/1999 & 600 & 500 & 0.22 & 0.4 \\
\hline II & $121 / 7$ & $29.283 \mathrm{~N}$ & $34.816 \mathrm{E}$ & 22/02/1999 & 850 & 845 & 0.76 & - \\
\hline II & $123 / 10$ & $29.284 \mathrm{~N}$ & $34.815 \mathrm{E}$ & 22/02/1999 & 850 & 845 & - & 18.5 \\
\hline III & $124 / 12$ & $29.083 \mathrm{~N}$ & $34.766 \mathrm{E}$ & 22/02/1999 & 835 & 835 & 0.68 & - \\
\hline III & $137 / 27$ & $29.084 \mathrm{~N}$ & 34.767E & 26/02/1999 & 840 & 470 & 0.18 & 1.8 \\
\hline IV & $125 / 13$ & $28.833 \mathrm{~N}$ & $34.734 \mathrm{E}$ & 23/02/1999 & 1445 & 1400 & 1.26 & - \\
\hline IV & $136 / 26$ & $28.834 \mathrm{~N}$ & $34.733 E$ & 25/02/1999 & 1415 & 1400 & - & 43.3 \\
\hline V & $118 / 4$ & $28.582 \mathrm{~N}$ & $34.651 \mathrm{E}$ & 21/02/1999 & 1200 & 1200 & 1.00 & - \\
\hline V & $126 / 14$ & $28.584 \mathrm{~N}$ & $34.650 \mathrm{E}$ & 23/02/1999 & 1200 & 300 & 0.08 & 0.6 \\
\hline V & $126 / 15$ & $28.584 \mathrm{~N}$ & $34.650 \mathrm{E}$ & 23/02/1999 & 1200 & 1200 & - & 33.6 \\
\hline $\mathrm{VI}$ & $117 / 3$ & $28.337 \mathrm{~N}$ & $34.551 \mathrm{E}$ & 21/02/1999 & 885 & 790 & 0.52 & 13.9 \\
\hline \multicolumn{9}{|c|}{ Northern Red Sea } \\
\hline VII & $144 / 35$ & $27.880 \mathrm{~N}$ & $34.666 \mathrm{E}$ & 27/02/1999 & 665 & 665 & 1.52 & 52.6 \\
\hline VIII & $145 / 36$ & $27.654 \mathrm{~N}$ & $34.668 \mathrm{E}$ & 27/02/1999 & 900 & 900 & 1.80 & 85.6 \\
\hline IX & $130 / 19$ & $27.418 \mathrm{~N}$ & $34.668 \mathrm{E}$ & 24/02/1999 & 880 & 880 & 3.32 & - \\
\hline$x$ & $131 / 20$ & $27.184 \mathrm{~N}$ & $34.666 \mathrm{E}$ & 24/02/1999 & 1140 & 1140 & 5.30 & 101.7 \\
\hline $\mathrm{XI}$ & $132 / 22$ & $27.298 \mathrm{~N}$ & $34.367 \mathrm{E}$ & 24/02/1999 & 1325 & 1325 & 4.93 & 119.1 \\
\hline XII & $149 / 42$ & $27.417 \mathrm{~N}$ & $34.084 \mathrm{E}$ & 28/02/1999 & 815 & 815 & 0.54 & 47.8 \\
\hline
\end{tabular}

3, 383-408, 2006

The northern Red

Sea - A system in balance?

C. Häse et al.

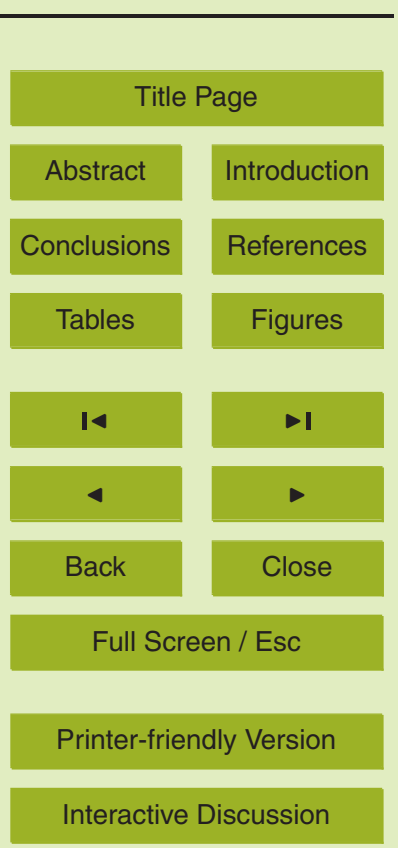




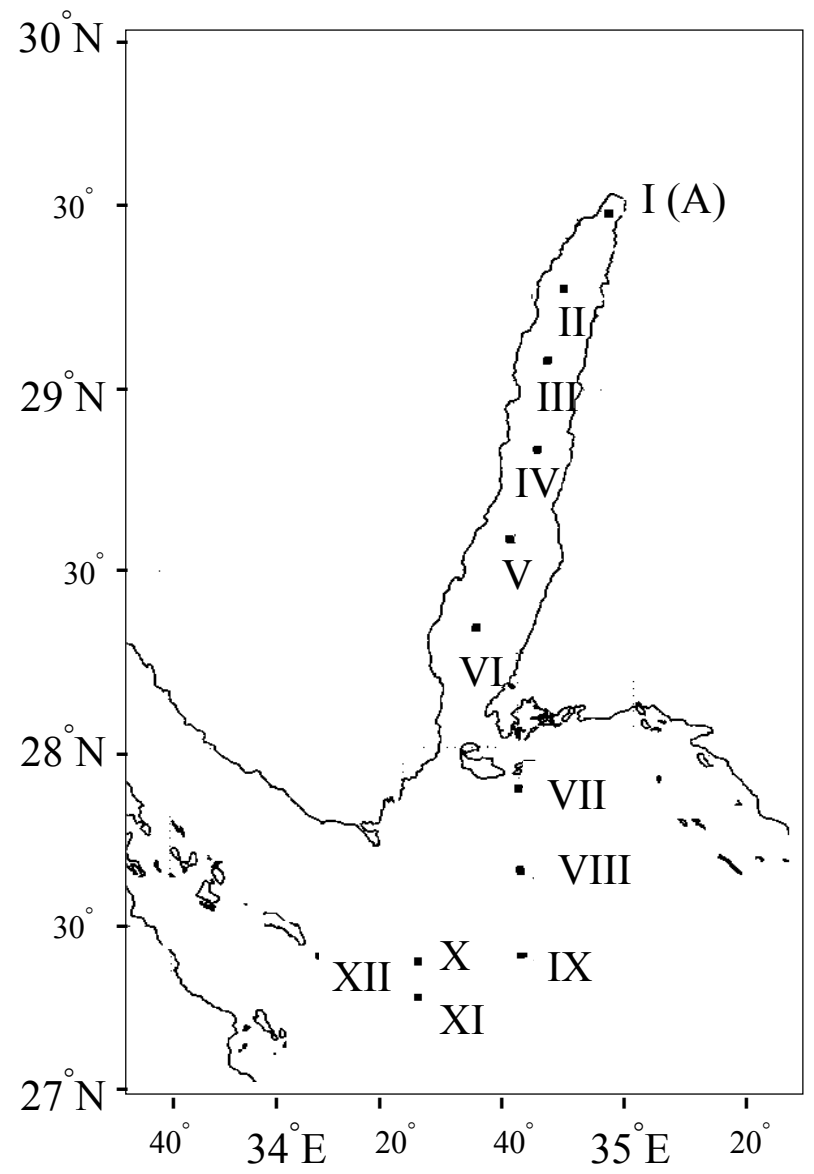

Fig. 1. Map of the study site indicating stations for water sample collection in the Gulf of Aqaba and the northern Red Sea during the RV "Meteor" cruise 44/2.

\section{BGD}

3, 383-408, 2006

\section{The northern Red}

Sea - A system in balance?

C. Häse et al.

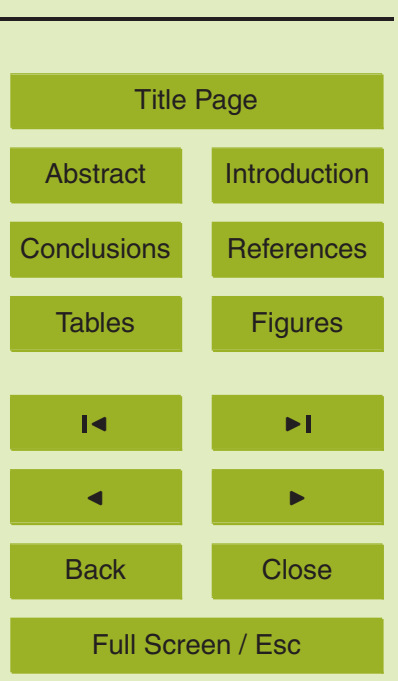

Printer-friendly Version

Interactive Discussion 
BGD

3, 383-408, 2006

The northern Red

Sea - A system in balance?

C. Häse et al.
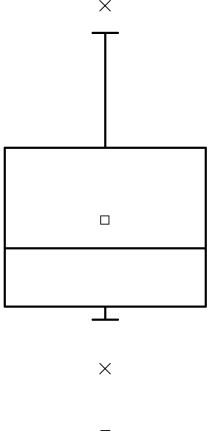

$-4-$

\section{Gulf of Aqaba}

Northern Red Sea

Fig. 2. Box-Whisker Plot of the nitrate deficit in both systems (numbers are given in Table 1).

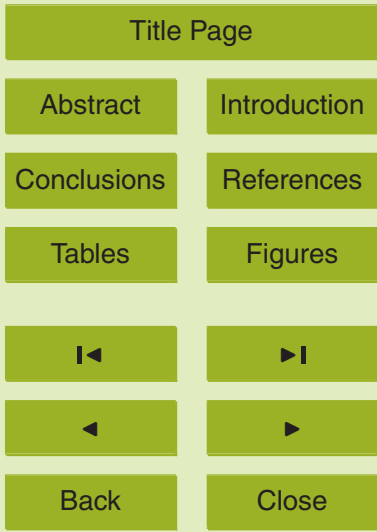

Full Screen / Esc

Printer-friendly Version

Interactive Discussion 


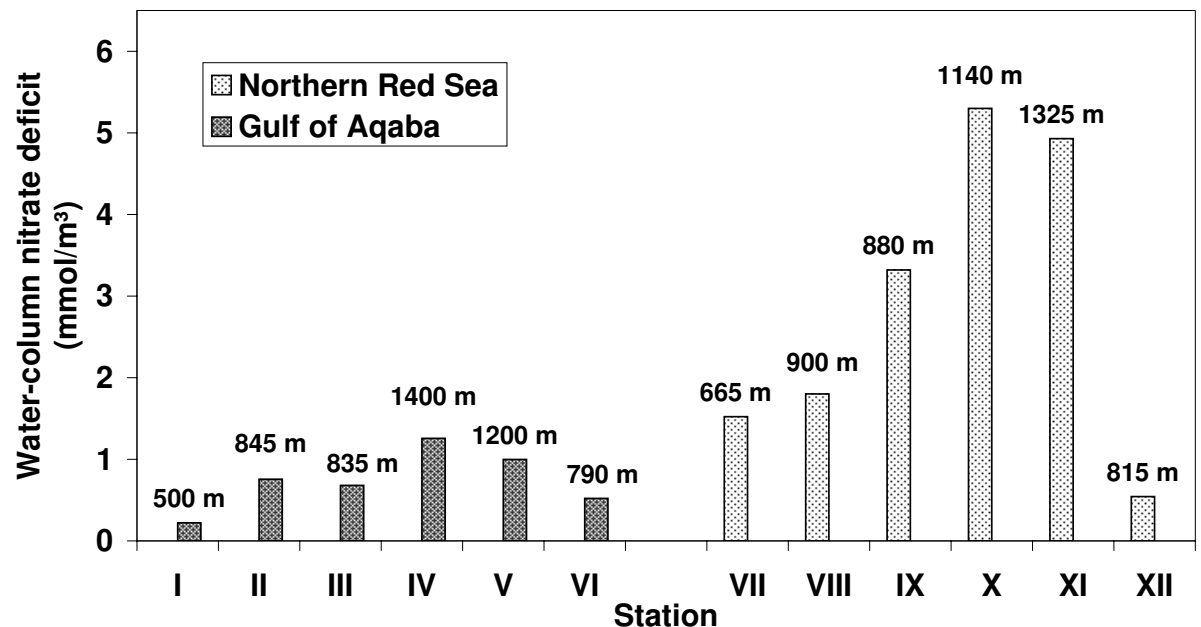

Fig. 3. Horizontal distribution of the water-column nitrate deficit in the Gulf of Aqaba (Stations $\mathrm{I}-\mathrm{VI}$ ), and in the northern Red Sea (Stations VII-XII; see Fig. 1). The values of the watercolumn nitrate deficits are given in Table 2 . The indicated depths refer to the maximum depth that was sampled at the respective station (see Table 2).
The northern Red

Sea - A system in balance?

C. Häse et al.

Title Page

Abstract

Introduction

Conclusions

References

Tables

Figures

14

4

Back

\section{Full Screen / Esc}

Printer-friendly Version

Interactive Discussion 
BGD

3, 383-408, 2006

The northern Red

Sea - A system in

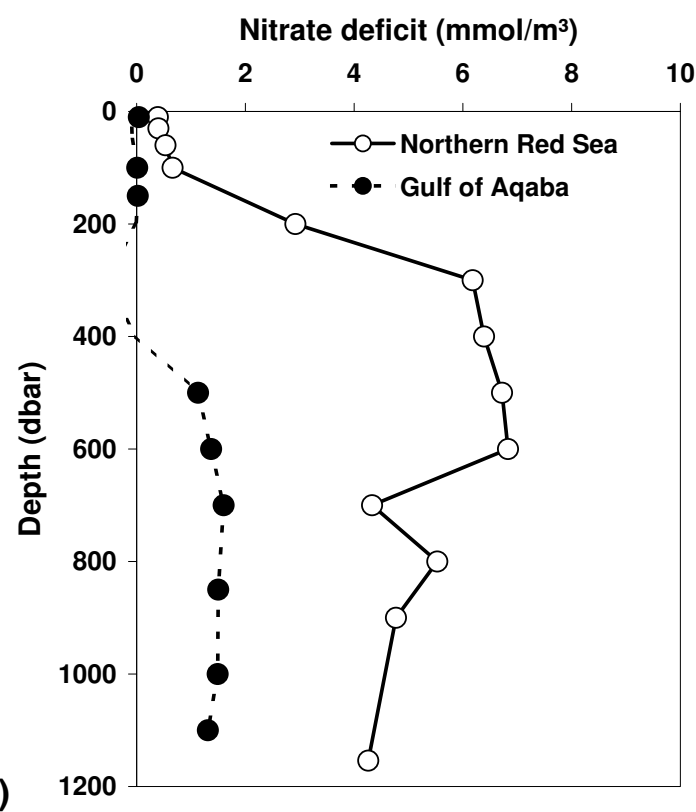

(a) (b)

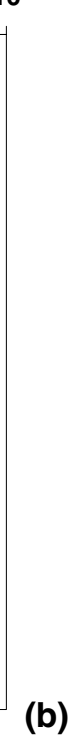

Fig. 4. (a) Typical vertical oxygen distribution in the Gulf of Aqaba and the northern Red Sea. (b) Corresponding vertical distribution of the nitrate deficit. Data from 21/2/1999, Station V, and from 24/2/1999, Station X.

\section{balance? \\ C. Häse et al.}

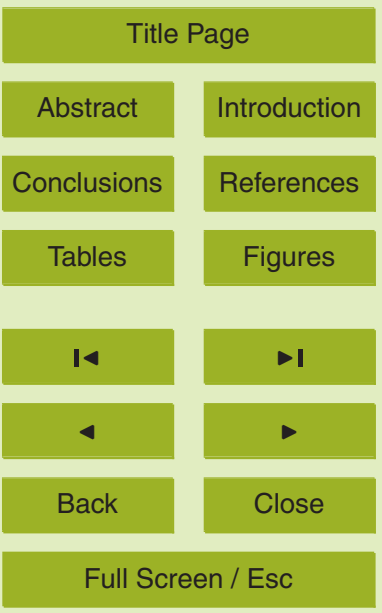

Printer-friendly Version

Interactive Discussion 
BGD

3, 383-408, 2006

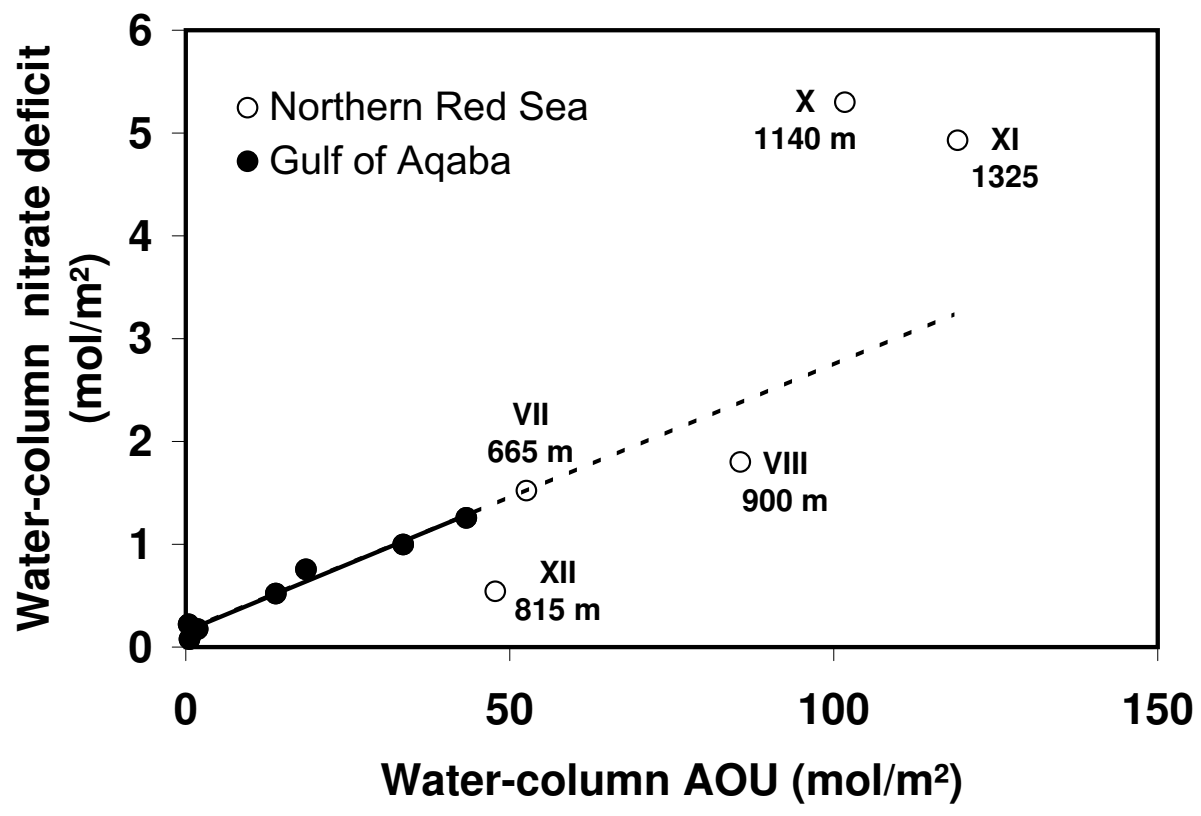

Fig. 5. (a) The nitrate deficit versus oxygen concentration in the Gulf of Aqaba and in the northern Red Sea. Note, that for stations IV and V nutrient and oxygen data are not from the same day (see Table 2). Note also, that the trendline corresponds to the data from the gulf, only. Station numbers and maximum sampling depths are indicated (Table 2).
The northern Red

Sea - A system in balance?

C. Häse et al.

Title Page

Abstract

Introduction

Conclusions

References

Tables

Figures

14

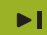

4

Back

Close

\section{Full Screen / Esc}

Printer-friendly Version

Interactive Discussion 


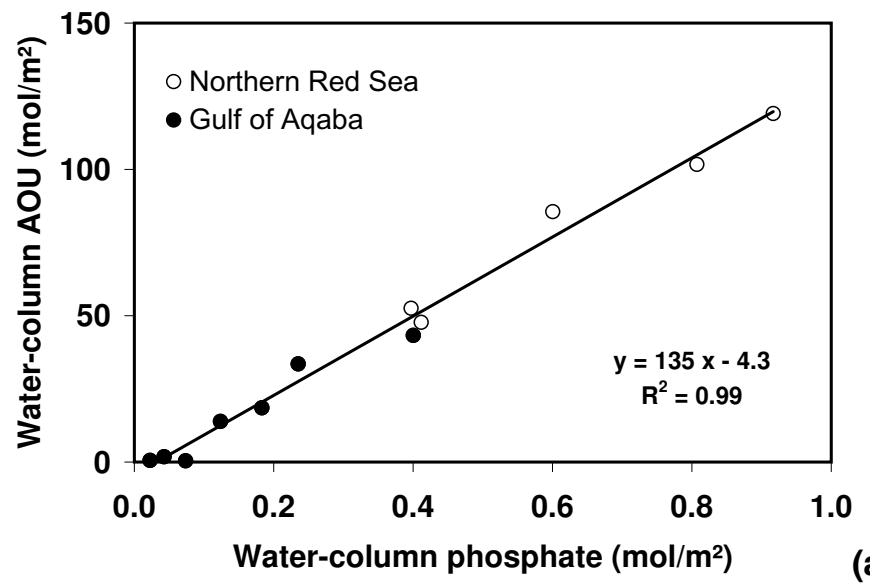

BGD

3, 383-408, 2006

The northern Red

Sea - A system in balance?

C. Häse et al.

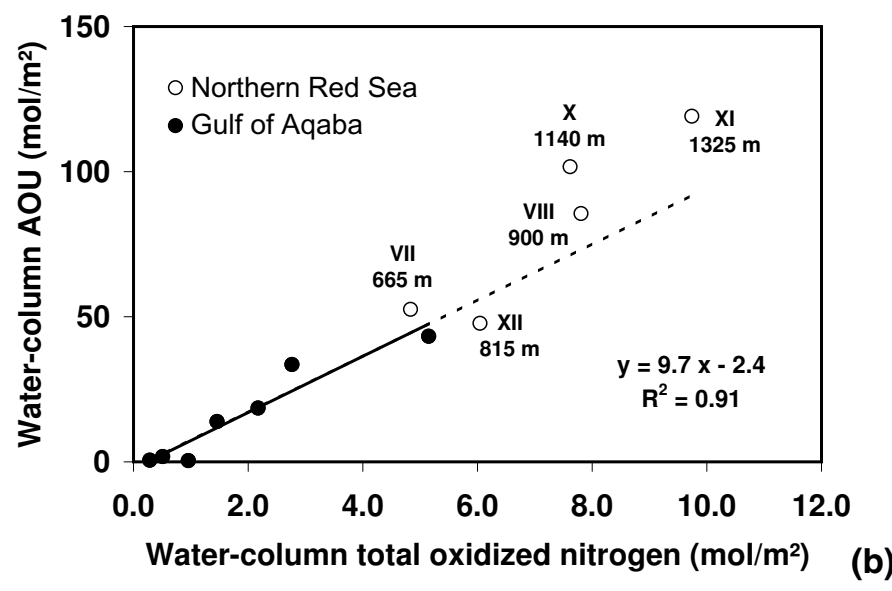

Title Page

Abstract

Introduction

Conclusions

References

Tables

Figures

14

$>$ I
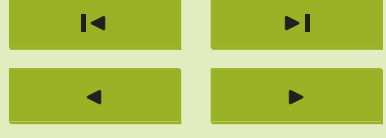

Back

Close

Full Screen / Esc

Printer-friendly Version

Fig. 6. Apparent oxygen utilization and nutrient remineralization of (a) phosphate, and (b) total oxidized nitrogen follow the "Redfield" stoichiometry in the Gulf of Aqaba and in parts of the Interactive Discussion northern Red Sea. Note, that for stations IV and V nutrient and oxygen data are not from the same day (see Table 2). Station numbers and maximum sampling depths are indicated (Table 2). 